\title{
Metabolic evaluation in overweight and obese cats and association with blood pressure
}

\author{
Vanessa Danielle de Freitas $^{1^{*}}$ Alessandra Ramos Castilho ${ }^{2}$ \\ Luciana Auxiliadora Viebrantz da Conceição ${ }^{1}$ Valéria Régia Franco Sousa ${ }^{4}$ \\ Adriane Jorge Mendonça ${ }^{4}$ Felipe Gomes da Silva ${ }^{3}$ Arleana do Bom Parto Ferreira de Almeida ${ }^{4}$
}

\footnotetext{
${ }^{1}$ Programa de Pós-graduação em Ciências Veterinárias, Universidade Federal de Mato Grosso (UFMT), 78060-900, Cuiabá, MT, Brasil. E-mail: vanessa.danielle@hotmail.com. "Corresponding author.

${ }^{2}$ Faculdade de Medicina Veterinária (FAVET), Universidade Federal de Mato Grosso (UFMT), Cuiabá, MT, Brasil.

${ }^{3}$ Departamento de Zootecnia e Extensão Rural (DZER), Faculdade de Agronomia e Zootecnia (FAAZ), Universidade Federal de Mato Grosso (UFMT), Cuiabá, MT, Brasil.

${ }^{4}$ Departamento de Clínica Médica Veterinária (CLIMEV), Faculdade de Medicina Veterinária (FAVET), Universidade Federal de Mato Grosso (UFMT), Cuiabá, MT, Brasil.
}

\begin{abstract}
Obesity has been increasing in cats andis associated with metabolic and cardiovascular diseases. The association of these alterations can trigger the onset of metabolic syndrome (MS). Therefore, this study aimed to analyze the serum levels of glucose, fructosamine, cholesterol, triglycerides, high-density lipoprotein, low-density lipoprotein, very low-density lipoprotein (VLDL), andalanine aminotransferase of cats and to identify the possibility of MS, as well as to evaluate changes in arterial pressure. Thirty-seven cats were classified by ECC and morphometric measurements, namely, 15 obese, 12 overweight, and 10 controls. Nocat manifested MS. Only VLDL had a statistically significant difference $(P<0.05)$ between groups. Therefore, obesity may not be associated with arterial hypertension, and more studies are needed to evaluate the metabolic alterations in overweight and obese cats.
\end{abstract}

Key words: obesity, cats, hypertension, dyslipidemia.

Avaliação metabólica em gatos com sobrepeso e obesos e sua associação com pressão arterial

RESUMO: Nos últimos anos, tem sido observado um aumento na incidência de obesidade em gatos, sendo associado a doenças metabólicas e cardiovasculares e a associação dessas alterações pode desencadear o surgimento de síndrome metabólica. Diante disto, o objetivo deste trabalho foi analisar os níveis séricos de glicose, frutosamina, colesterol, triglicerídeos, HDL, LDL, VLDL e ALT dos gatos e identificar uma possivel presença de síndrome metabólica nos mesmos, além de avaliar a ocorrência de alterações na pressão arterial. Utilizaram-se 37 gatos, classificados através de ECC e medidas morfométricas em 15 obesos, 12 sobrepesos e 10 controles. Nenhum gato do estudo manifestou síndrome metabólica. Apenas o VLDL obteve diferença estatisticamente significativa $(P<0.05)$ entre os grupos. Concluiu-se que a obesidade pode não estar associada à hipertensão arterial e que se necessita de mais estudos para avaliar as alterações metabólicas em gatos com sobrepeso e obesos.

Palavras-chave: obesidade, gatos, hipertensão, dislipidemia.

Obesity is considered the most commonnutritional problem in dogs and cats, and it is influenced by genetic, social, cultural, and individual factors, such as sex, race, age, physical inactivity, neutering, and medications (ZORAN, 2010). Techniques to determine the body condition score (ECC) and morphometric measurements are used routinely for diagnosis (LAFLAMME, 2006). In addition, obesity is related to a series of metabolic and cardiovascular alterations in humans. Association of some of these alterations may trigger the emergence of metabolic syndrome (MS), where obesity is considered the main factor involved.MS represents a set of risk factors that can promote the development of metabolic abnormalities and cardiovascular diseases, such asdiabetes mellitus, dyslipidemia, and hypertension (CLARK \& HOENIG, 2016). According to MORI 
et al. (2012), for the diagnosis of MS in cats, they must present central obesity, which is defined as an increase of $>10 \%$ normal body weight or ECC $>5$ (9-point scale)andtwo of the following factors:serum glucose levels $\geq 120 \mathrm{mgdL}^{-1}$, serum triglyceride levels $\geq 165 \mathrm{mgdL}^{-1}$, total cholesterol $\geq 180 \mathrm{mgdL}^{-1}$, and serum alanine aminotransferase (ALT) $\geq 100 \mathrm{IU}$. Additionally, the diagnosismay be confirmed by the serum adiponectin dosage $\left(<3.0 \mu \mathrm{gmL}^{-1}\right)$ or serum insulin levels $\left(>3.0 \mathrm{ngmL}^{-}\right.$ $\left.{ }^{1}\right)$. Increase in systemic blood pressure related to obesity in cats is still controversial, and there is no evidence of association between them (PEREIRANETO et al., 2009). The literature on the effects of obesity on metabolic and cardiac functions in cats is still limited.Therefore, the present study aimed to evaluate the serum levels of glucose, fructosamine, cholesterol, triglycerides, highdensity lipoprotein (HDL), low-density lipoprotein (LDL), very low-density lipoprotein (VLDL), and ALT in overweight and obese cats,to identify the presence of metabolic disorders similar to MS in humans, characterized by hypercholesterolemia, hypertriglyceridemia, and hyperglycemia,andto evaluate changes in blood pressure.

In the present study, 37 adult cats, aged 3-14 years, were evaluated, independent of sex and race and castrated and not castrated, from the clinical care of the Veterinary Hospital. Cats should be healthy during the visit,and only those who came for routine carewere enrolled in the study. They were divided into three groups according to the body condition score based on LAFLAMME (1997) and morphometric measurements (BUTTERWICK, 2000), namely, obese (ECC 8-9), overweight (ECC 6-7), and control groups (ECC 5).

A complete clinical examination was performed, and information was obtained, such as medication use in the last three months and preexisting diseases as exclusion criteria.Posteriorly, the cats were fasted for 12 hours, and blood samples were collected by cephalic or jugular venipuncture and placed in tubes without anticoagulant $( \pm 5 \mathrm{~mL})$ for serum and in tubes containing sodium fluoride $(2 \mathrm{~mL})$ for serum glucose dosing. Levels of ALT (kinetic-UV method), cholesterol, triglycerides, HDL, serum glucose (enzymatic-colorimetric), and serum fructosamine (kinetic-colorimetric) were obtained using a semiautomatic biochemical analyzer (SB $\left.190 \mathrm{CELM}^{\circledR}\right)$, with the use of specific commercial kits (Analisa ${ }^{\mathbb{}}$, Minas Gerais, Brazil) following manufacturer's guidelines. LDL and VLDL dosages were calculated using the equationby FRIEDEWALD et al. (1972).
Systolic, diastolic, and mean blood pressure measurements were performed in triplicates(three measurements with a 5-minute interval) in a quiet environment using the PetMAP ${ }^{\circledR}$ device following manufacturer's guidelines.

SAS University Edition software was used for statistical analysis. The MEANS procedure was used for descriptive analysis, CORR to calculate the Pearson correlations, ROBUSTREG for outlier detection, GLMSELECT to detect the best observational statistical model, UNIVARIATE for normality tests, GLM for analysis of variance, and mean tests of Tukey $(\mathrm{P}<0.05)$.

Of the 37 cats, $15(40.5 \%)$ were classified as obese, and $12(32.5 \%)$ were overweight. The control group comprised $10(27 \%)$ cats. The obese group had $12(80 \%)$ males and three females $(20 \%)$; the overweight group had five (41.6\%) males and seven females (58.4\%); and the control group had four males $(40 \%)$ and six $(60 \%)$ females. The mean age of cats was $4.9 \pm 2.6$ years. All cats were of undefined race.

Results of the morphological analyses of body weight (CP), ECC, body mass index (BMI), percentage of body fat ( $\% \mathrm{GC})$, and abdominal circumference (CA) and biochemical and blood pressure analyses are described as mean \pm standard deviation (SD) according to the groups, as shown in table 1. A percentage increase of $33.3 \pm 7.7 \%$ of CP, BMI, $\mathrm{GC}$, and $\mathrm{CA}$ of the obese cats was observed in relation to the control group. In the GLMSELECT procedure, it was observed that an increase in $1 \%$ of body fat leads to a $1.1 \mathrm{mgdL}^{-1}$ increase in glucoseand $1.08 \mathrm{mgdL}^{-}$ ${ }^{1}$ increase in LDL. A 1-unit riseinBMI increases the triglycerides by $5.6 \mathrm{mgdL}^{-1}$ and VLDL by $1.15 \mathrm{mgdL}^{-1}$ and an increasein one year increases cholesterol levels by $2.16 \mathrm{mgdL}^{-1}$ and LDL by $1.66 \mathrm{mgdL}^{-1}$.

No cats were diagnosed with metabolic disorder, and five cats had fasting hyperglycemia, namely, one in the control $\left(207 \mathrm{mgdL}^{-1}\right)$, one in the overweight $\left(130 \mathrm{mgdL}^{-1}\right)$, and three in the obese $\left(139 \pm 18.2 \mathrm{mgdL}^{-1}\right)$ groups. The HDL levels of cats ranged from 22 to $105 \mathrm{mgdL}^{-1}$, LDL levels ranged from 8 to $91 \mathrm{mgdL}^{-1}$, and VLDL levels ranged from 4 to $30.6 \mathrm{mgdL}^{-1}$. The means and SD according to the groups are presented in table 1 , which areused as reference values of the control group. There was no statistical difference between the variables, namely, cholesterol, triglycerides, LDL, and HDL $(\mathrm{P}>0.05)$. However, a statistical difference was observed between the groups in relation to VLDL levels $(\mathrm{P}<0.05)$.

Of the 37 cats evaluated, 19 were hypertensive:four (21.05\%) in the control group, seven $(36.85 \%)$ in the overweight group, and eight $(42.10 \%)$ 
Table 1 - Variables evaluated in cats from clinical care (mean \pm standard deviation).

\begin{tabular}{lccc}
\hline Variable & Obese $(\mathrm{N}=15)$ & Overweight $(\mathrm{N}=12)$ & Control $(\mathrm{N}=10)$ \\
\hline Weight $(\mathrm{kg})$ & $5.6 \pm 0.81$ & $4.6 \pm 0.62$ & $3.6 \pm 0.37$ \\
ECC & 8.0 & $6.6 \pm 0.51$ & 5.0 \\
BMI & $14.3 \pm 1.75$ & $11.2 \pm 1.48$ & $9.2 \pm 0.77$ \\
GC $(\%)$ & $41.4 \pm 7.23$ & $32.1 \pm 6.73$ & $24.4 \pm 4.47$ \\
CA $(\mathrm{cm})$ & $48.9 \pm 4.00$ & $43.8 \pm 4.20$ & $37.6 \pm 4.03$ \\
Glucose $(\mathrm{mg} / \mathrm{dL})$ & $98.4 \pm 24.47$ & $91.5 \pm 18.85$ & $94.6 \pm 44.69$ \\
Fructosamine $\left(\mathrm{mmol} \mathrm{L}^{-1}\right)$ & $1.52 \pm 0.41$ & $1.5 \pm 0.64$ & $1.73 \pm 0.53$ \\
Triglycerides $\left(\mathrm{mgdL}^{-1}\right)$ & $60.3 \pm 21.85$ & $71.6 \pm 41.63$ & $41.8 \pm 10.18$ \\
Cholesterol $\left(\mathrm{mgdL}^{-1}\right)$ & $110.2 \pm 24.21$ & $61.6 \pm 16.23$ & $106 \pm 21.77$ \\
HDL $\left(\mathrm{mgdL}^{-1}\right)$ & $64.9 \pm 16.67$ & $37.9 \pm 23.65$ & $50.2 \pm 15.71$ \\
LDL $\left(\mathrm{mgdL}^{-1}\right)$ & $33.2 \pm 18.97$ & $13.8 \pm 8.45 \mathrm{ab}$ & $45.5 \pm 20.48$ \\
VLDL $\left(\mathrm{mgdL}^{-1}\right)$ & $12.14 \pm 4.23 \mathrm{a}$ & $54.25 \pm 15.37$ & $8.36 \pm 2.03 \mathrm{~b}$ \\
ALT $\left(\mathrm{UL}^{-1}\right)$ & $60.4 \pm 14.15$ & & $66.7 \pm 31.93$ \\
\hline
\end{tabular}

ECC, body condition score; BMI, body mass index; GC, body fat; CA, abdominal circumference; SBP, systolic blood pressure; DBP, diastolic blood pressure; MAP, mean arterial pressure. Means followed by different letters in the same row differ statistically from each other by the Tukey test $(\mathrm{P}<0.05)$.

in the obese group. In the analysis between the groups, there was no statistical difference between them $(\mathrm{P}>0.05)$ (Table 2). The Pearson correlation test revealed a low and positive correlation between systolic blood pressure (SBP) and triglycerides $(\mathrm{r}=0.15), \mathrm{SBP}$ and cholesterol $(\mathrm{r}=0.25), \mathrm{SBP}$ and VLDL $(\mathrm{r}=0.15), \mathrm{PAD}$ and triglycerides $(\mathrm{r}=0.19)$, PAD and cholesterol $(\mathrm{r}=0.27)$, and DBP and VLDL $(\mathrm{r}=0.21)$ but a high and positive correlation between triglycerides and VLDL $(r=0.98)$.

In the growth of the feline population, obesity tends to show a positive correlation between $\mathrm{ECC}, \mathrm{PC}, \mathrm{BMI}, \% \mathrm{GC}$, and $\mathrm{CA}$, as observed in this study and mentioned by APTEKMANN (2014). In the present study; although, no significance analysis was performed regarding the age of the cats, a correlation was detected between age and the cholesterol and LDL index, corroborating the results obtained by
COLLIARD et al. (2009), who reported that older cats are more predisposed to obesity.

In cats, transient hyperglycemia can be caused by stress, but a serum dosage of fructosamine, as performed in this study, helps in the exclusion of the hyperglycemic state (LUTZ et al., 1995), as observed in the catsin the present study who presented with hyperglycemia becausethe fructosaminelevelswere found within normal parameters.

Although, there was no statistically significant difference in cholesterol, triglyceride, and LDL levels between the control and obese groups, similar to the study by JORDAN et al. (2008), their levels were higher than expected in the obese and overweight groups, based on human data. However, an important aspect was the non-decreasing HDL levels in these animals, as occurs in humans, but this

Table 2 - Blood pressure of cats from clinical care (mean \pm standard deviation).

\begin{tabular}{lccr}
\hline Blood pressure & Obese & Overweight & Control \\
\hline PAD $(\mathrm{mmHg})$ & $108.5 \pm 17.2$ & $106 \pm 33.2$ & $98.5 \pm 24.6$ \\
PAM $(\mathrm{mmHg})$ & $129.7 \pm 19.5$ & $130.7 \pm 20.85$ & $119 \pm 25.3$ \\
PAS $(\mathrm{mmHg})$ & $168.6 \pm 29.45$ & $170 \pm 9.6$ & $159.6 \pm 36.4$ \\
\hline
\end{tabular}

DBP, diastolic blood pressure; MAP, mean arterial pressure; SBP, systolic blood pressure. 
analysis could not be confirmed because measuring the obesity time of the cats evaluated was impossible.

The increase in HDL, triglyceride, and VLDL levels, with a statistically significant difference in VLDL between the three groups, is similar to that observed by HOENIG et al. (2003), where they described that newly obese cats presented an increase in HDL and VLDL levels. In dogs and cats, dyslipidemia does not appear to induce atherosclerosis as in humans. This phenomenon can be related to the lipid metabolism of these species, which is characterized by higher levels of circulating HDL, which makes them more resistant to the development of atherosclerosis (HOENIG et al., 2003), justifying the absence of low levels of HDL in overweightand obese cats evaluated.

The increase in triglyceridesthat correlated positively with that in VLDL in the present study is in agreement with NAKAYA (2002), who reported that such correlation existed because VLDL is a lipoprotein rich in triglycerides. However, although their increase was associated with an increased risk of cardiovascular diseases in humans, it was not possible to infer this in the cats evaluated. This phenomenon is in view of the non-correlation between their serum levels and increase in systolic and/or diastolic blood pressure, although $51.3 \%$ of the cats had hypertension. The low number of cats included in the present study may have been a limiting factor for the absence of statistical significance of the occurrence of hypertension between groups. According to CHANDLER (2016), whether obesity is a risk factor for hypertension in cats has not yet been reported. According to BELEW (1999), interpretation in cats should be performed judiciously because increases in blood pressure may be due to sympathetic activation in response to stress, as occursin several species.

Although, no cat in the overweight and obese groups had MS and no correlation between obesity and variables analyzed was reported, the increased levels of cholesterol, triglycerides, and VLDL in overweight and obese cats may indicate cardiovascular changes in this species, as reported in humans. However, further studies with a larger number of cats anda longer follow-up should be conducted to better characterize the association between obesity and blood pressure increase in domestic cats.

\section{BIOETHICS AND BIOSSECURITY COMMITTEE APPROVAL}

This study was approved by the Ethics Committee for the Use of Animals of the Universidade Federal de Mato Grosso (UFMT), Brazil, under protocol number 23108.115855/2015-26.

\section{ACKNOWLEDGEMENTS}

Alessandra Ramos Castilhos has a fellowship from Conselho Nacional de Desenvolvimento Científico e Tecnológico (CNPq) (PIBIC/CNPq/UFMT.)

\section{REFERENCES}

APTEKMANN, K.P. et al. Comparison of different methods of body assessing in cats. Revista Brasileira de Medicina Veterinária, v.36, n.2, p.215-218, 2014.Availablefrom: $<$ http:// www.rbmv.com.br/pdf_artigos/10-12-2014_17-32RBMV043. pdf>. Accessed: Nov.28, 2016 .

BELEW, A. et al. Evaluation of white-coat effect in cats. Journal of Veterinary Internal Medicine, v.13, p.134142, 1999. Available from: <http://onlinelibrary.wiley.com/ doi/10.1111/j.1939-1676.1999.tb01141.x/epdf>. Accessed: Nov. 15, 2016. doi: 10.1111/j.1939-1676.1999.tb01141.x.

BUTTERWICK, R. How fat is that cat? Journal of Feline Medicine and Surgery, v.2, p.91-94, 2000. Available from: $<$ http://journals.sagepub.com/doi/pdf/10.1053/jfms.2000.0078>. Accessed: Sept.12,2016.

CHANDLER, M.L. Impact of obesity on cardiopulmonary disease. Veterinary Clinics of North America: Small Animal Practice, v.46, n.5, p.817-830, 2016. Available from: <http:// www.sciencedirect.com/science/article/pii/S0195561616300213>. Accessed: June 06, 2017. doi: 10.1016/j.cvsm.2016.04.005.

CLARK, M.; HOENIG, M. Metabolic effects of obesity and its interaction with endocrine diseases. Veterinary Clinics of North America: Small Animal Practice, v.46, n.5, p.797-815, 2016. Available from: $<$ http://www.sciencedirect.com/science/article/pii/ S0195561616300201>. Accessed: June 06, 2017. doi: 10.1016/j. cvsm.2016.04.004.

COLLIARD, L. et al. Prevalence and risk factors of obesity in an urban population of healthy cats. Journal of Feline Medicine and Surgery, v.11, p.135-140, 2009. Available from: <http://www. sciencedirect.com/science/article/pii/S1098612X08001587>. Accessed: Feb. 02, 2017. doi: 10.1016/j.jfms.2008.07.002.

FRIEDEWALD, W.T. et al. Estimation of the concentration of low density lipoproteinscholesterol in plasma without use of the ultracentrifuge. Clinical Chemistry, v.18, p.499-502, 1972. Available from: <http://clinchem.aaccjnls.org/content/ clinchem/18/6/499.full.pdf>. Accessed: July 28, 2016.

HOENIG, M. et al. Effects of obesity on lipid profiles in neutered male and female cats. American Journal of Veterinary Research, v.64, n.3, p.299-303, 2003. Available from: <https://www. researchgate.net/publication/10833797_Effects_of_obesity_on lipid_profiles_in_neutered_male_and_female_cats $>$. Accessed: July 17, 2016. doi: 10.2460 /ajvr.2003.64.299.

JORDAN, E. et al. Dyslipidemia in obese cats. Domestic Animal Endocrinology, v.35, p.290-299, 2008. Available from: <http:// www.sciencedirect.com/science/article/pii/S0739724008000660>. Accessed: July 12, 2016.doi: 10.1016/j.domaniend.2008.05.008.

LAFLAMME, D.P. Development and validation of a body condition score system for cats: a clinical tool. Feline Practice, v.25, n.5-6, p.13-17, 1997. Available from: <https://www. 
researchgate.net/publication/289792900_Development_and_ validation_of_a_body_condition_score_system_for_cats_A clinical_tool $>$. Accessed: July 12, 2016.

LAFLAMME, D.P. Understanding and managing obesity in dogs and cats. Veterinary Clinics of North America: Small Anima Practice, v.36, p.1283-1295, 2006. Available from: <http://www. vetsmall.theclinics.com/article/S0195-5616(06)00096-9/fulltext $>$. Accessed: Sept.15, 2016. doi: 10.1016/j.cvsm.2006.08.005.

LUTZ, T.A. et al. Fructosamine concentrations in hyperglycemic cats. Canadian Veterinary Journal, v.36, n.3, p.155-159,1995. Available from: <https://www.ncbi.nlm.nih.gov/pmc/articles/ PMC1686902/>. Accessed: Feb.10, 2017.

MORI, N. et al. Establishment of temporary criteria for metabolic syndrome (MS) diagnosis and assessment of the occurrence rate of MS in cats. Journal of Animal and Veterinary Advances, v.11, n.5, p.615-617, 2012. Available from: <http://medwelljournals. com/abstract/?doi=javaa.2012.615.617>. Accessed: July 20, 2015. doi: 10.3923/javaa.2012.615.617.

NAKAYA, N. Hypertriglyceridemia as a cause of atherosclerosis. Nippon Rinsho, Japanese Journal of Clinical Medicine, v.60, n.5, p.860-867, 2002. Available from: <https://www.researchgate. net/publication/11342418_Hypertriglyceridemia_as_a_cause_of_ atherosclerosis>. Accessed: Feb.15, 2017.

PEREIRA-NETO, G.B. et al. Effects of weight loss on the cardiac parameters of obese dogs. Pesquisa Veterinária Brasileira, v.30, n.2, p.167-171, 2010. Availablefrom: <http://130.211.64.33/pdf_ artigos/01-03-2010_00-57Vet785.pdf>. Accessed: Oct.15,2016.

ZORAN, D.L. Obesity in dogs and cats: a metabolic and endocrine disorder. Veterinary Clinics of North America: Small Animal Practice, v.40, n.2, p.221-239, 2010. Available from: <http:// www.sciencedirect.com/science/article/pii/S0195561609001806>. Accessed: Dec.12, 2016. doi: 10.1016/j.cvsm.2009.10.009. 